\title{
Strange Third Ways and the LSE Affair
}

\section{Roland Robertson}

Published online: 21 May 2011

(C) Springer Science+Business Media, LLC 2011

An academic scandal of global significance has blown up concerning, inter alia, the acceptance of "blood money" by the London School of Economics from the Gaddafi regime. This particular epithet has been used by one of Saif Gaddafi's PhD examiners, Lord Desai, an Emeritus Professor at the LSE. This scandal has mainly revolved around the $\mathrm{PhD}$ awarded to this son of the Brother Leader and the associated money later awarded to the LSE (although some of it has been declined). In what follows I attempt to situate what has become known as the LSE affair in a broad global context.

At the outset I should state that I spent a year or more as a postgraduate student and a research assistant at the LSE in the early 1960s and was proud to have been at this illustrious institution. Moreover, I had the pleasure of attending the weekly seminars conducted by the late Jewish Marxist, Ralph Miliband, the father of Ed and David. My supervisor was Tom Bottomore. I greatly enjoyed the friendship of fellow students from many different countries, not to speak of having access to some of the most renowned social scientists and philosophers in the world. These circumstances make it very sad that I should now find myself writing about such an ugly and self-harming series of events at the LSE.

In about 50 years as a full-time academic, approximately one half of which was spent in the USA, I have encountered both in the UK and the USA a significant number of academic scandals: nepotism, misuse of grants and university monies, blatant favouritism, and sleaze. I learned long ago that universities are not exceptional

R. Robertson $(\bowtie)$

The School of Social Science, University of Aberdeen, Aberdeen, England AB24 3QY, UK

e-mail: r.robertson@abdn.ac.uk institutions, in the sense that they are not without dishonesty or, indeed, corruption. My academic career has covered the period of such scandalous events as Project Camelot in Latin America, the overthrow of Allende in Chile and the support given to his "successor," Pinochet, by academics. Long ago - in fact by the mid 1970s - I had become aware of the increasingly tyrannical Libyan regime. Indeed, I objected to some members of my own university of that time for being involved in Libyan affairs. Moreover, I also encountered academic corruption with respect to the USA's involvement in Indochina. As Director of Graduate Studies in a large sociology department I frequently encountered the many dubious applications from "foreign" students, particularly after the "opening" of the Peoples' Republic of China in the early 1970s. Nothing, however, can match the events at the LSE during the last 12 years or so, events that came to a head with the Gaddafi-related incidents indicated above, although I readily concede that more recent and continuing civil strife in Libya has made these appear much worse. I emphasize, however, that no comfort should be taken from or given to the people involved at the LSE. The LSE scandal should not be relativized.

I fully realize that UK universities are currently under great financial pressure and that the social sciences, in particular, had to withstand attacks during the Thatcher years, as well as the still-mounting onslaught on universities by the present "Con-Dem" government; although a little of the criticism has been justified. In the current situation a large number of UK universities have sought and/or accepted finance from authoritarian - not to say totalitarian-regimes. For reasons of space I cannot discuss this here, although it should be noted that the excessive salaries and perks awarded to senior university administrators has, for long, been an outrage in the UK and the USA. 
The dubious acceptance of Said Gaddafi as a postgraduate student, his subsequent obtaining of a now-heavily disputed $\mathrm{PhD}$, his financial gifts to his alma mater, his widely known profligate lifestyle and luxurious properties in a number of countries, his prestigious external and informal advisers and - not least and ironically-his invitation to give the Ralph Miliband lecture, add up to an egregious set of circumstances that is hard to believe or, indeed, miss. To make matters worse it has been extremely difficult to get anybody in a formal position at the LSE- or even in offices of professional organizations such as the British Sociological Association or the Political Studies Association - to respond to reasonable requests for comments on the whole, or at least aspects, of the affair. On the other hand, a considerable number of LSE students have expressed outrage.

I am writing this at the very end of March, 2011, not long after a special investigatory committee headed by Lord Woolf has been established at the LSE. I have noted, however, that up to this point relatively little attention has been given to the activities of the LSE Director who preceded Sir Howard Davies, the Director who recently resigned. I refer of course to Baron Anthony Giddens, who seems to have escaped most of the "flak" that has been directed against the LSE. However, as one can easily discover, it was Lord Giddens who was apparently central to the establishment - or at least consolidation of - the links between the fascistic Libyan government and the LSE itself. Moreover, when Giddens visited Gaddafi in 2006 and 2007 it has been widely recorded that he found hope for and, indeed, was optimistic about the future of Libya. In this connection it should be mentioned that Giddens became largely known in the latter part of his career to date for his advocacy of the so-called Third Way. It was apparently mostly because of this that he was awarded a peerage by his friend, the then Prime Minister, Tony Blair in 2004. Blair himself had become particularly notorious for the photographs of him embracing Gaddafi in the Libyan desert in that same year. This event was subsequently followed by the release of the so-called Lockerbie Bomber, who allegedly was responsible - at least in partfor the airplane crash that led to the deaths of 270 passengers, 190 of whom were American citizens or residents, as well as people on the ground. Al Megrahis's release created much controversy between the US, Scottish, and the UK governments; not least because he was released on the grounds of rapidly failing heath, although he is still alive about 2 years later.

Giddens' book entitled The Third Way (2000) was published after Beyond Left and Right (1994). The latter had gained considerable attention in Labour Party elite circles, but The Third Way appeared to clinch his centrality, not least because the Labour Party had been out of office for many years. Giddens quickly became an adviser to Tony Blair, Blair having become the leader of what he called New Labour following the death of John Smith in 1994. Giddens' ventures into political writing in the years 1994 to 2000 were followed by The Third Way and Its Critics (2000) and the edited The Global Third Way Debates (2001). Many of his books had been published by Polity Press, which he himself had co-founded with David Held, a colleague who has been at the very centre of the Saif Gaddafi affair, who has also published many books with Polity. On the occasion of Giddens' appointment as Director of the LSE an announcement was made by the latter that a major reason for his appointment as Director was his entrepreneurial skills in the successful establishing of Polity Press.

Giddens maintained that he had discovered a new way of looking at politics, how to be left but without being too right. In fact, in advocating a third way between the left and the right, Giddens had a very large number of precursors, among them Kremalist Republicanism, Italian Fascism, and National Socialism, not to speak of many more mainstream and less controversial political intellectuals. To this very partial list must be added the name of Muammar al-Qaddafi who was by the early 1980 s, at the very latest, becoming widely known for his brand of The Third Universal Doctrine that was published in his little Green Book. Of course, this title constituted an emulation of Mao's Little Red Book, which at least had the merit of being comprehensible, even though supposedly written by yet another great dictator.

It should also be emphasized that by the time of his third-way, political turn Giddens had had become internationally prominent through his prolific writings in theoretical sociology and had, indeed, been awarded the accolade of giving the BBC's globally known, Reith Lectures. At the time of his becoming very cosy with New Labour leaders many sociologists began to wonder why he had risked tying his academic reputation to the future of a particular politician, who - as it turned out - became a world leader in the invasion of Iraq, along with his close ally George Bush Jr, not to speak of his openly expressed commendation of Gaddafi. Around the time of Blair's resignation in June, 2007, Giddens published yet another book, with the title, Over to You, Mr Brown, the introduction to which is highly self-referential and expresses his hope for the continuation and modernization of the policies that had been pursued by Blair. In fact, the book on Brown was highly praised in a number of Blairite circles.

The actual circumstances surrounding the supervision and examination of Saif Gaddafi remain largely a mystery-at least to those outside the LSE. David Held, the co-director of what Hugh Muir has called the "Gaddafi-tarnished School of Global Governance" (The Guardian, March 29, 2011, p.13) 
has played a very controversial part in this debacle, even though he was neither Saif's formal supervisor nor a member of his $\mathrm{PhD}$ examining committee. In any case, regardless of the minutiae of the whole circumstance, Held as a so-called global social scientist should surely have known a great deal more about Libya, North Africa and yet other regions. After all, the Brother Leader (Saif's father) had featured extensively, if intermittently, on the world stage for many years. Surely, at the very least, Held had the intellectual responsibility to have inspected the Green Book, as did his friend Giddens (although it should be stressed that, as far as I know, Giddens had no formal supervisory or examinationary role with Saif Gaddafi).

Hugh Muir concludes his pithy piece, referred to above, by asking the question: "Can anyone save the LSE from self-harm?" Muir's column in toto concerns the recent appointment, but abrupt resignation, of a man named Nir Rosen who had been offered a research fellowship at the LSE, following his ignominious departure from New York University. Rosen had, apparently, made light of the sexual abuse suffered by a TV reporter who had been covering the Egyptian "revolution." This is but one example of the ripple effect of the LSE scandal. One could also explore, given the space, such circumstances as dubious connections on the part of the Gadaffis with a Hollywood film company,
Natural Selection, as well as the frequently mentioned Monitor Group (which, at least originally, had Sir Howard Davies as one of its members). The major purpose of this group seems to have been the creation of a strategy to enhance the profile of Libya and Muammar Gaddafi and whose clients included Sir David Frost, Lord Anthony Giddens, and other academics of world standing none of whom has been willing to declare the fees that they were paid. It should be said, however, that a number of nonacademic celebrities who visited Libya to perform for the Brother Leader have returned their fees. The list of meetings between Saif and the global high-rollers would also include such people as that Prince of Darkness, Peter Mandelson (whose autobiography is titled The Third Man) and even a leader of the Unification Church (the Moonies).

All in all, serious, ethically sensitive academics have a great deal to learn from the (unfinished) case of Saif Gaddafi and his intellectual overseers at the LSE. The term "public intellectual" has, indeed, been sullied.

Roland Robertson is Distinguished Service Professor of Sociology Emeritus, University of Pittsburgh and Emeritus Professor of Sociology and Global Society, University of Aberdeen. 